\title{
Development of Seismic Fragility Curves of RC Infilled Frame Buildings in Jordan
}

\author{
Hanan Al-Nimry ${ }^{1, *}$ \\ ${ }^{1}$ Jordan University of Science and Technology, Civil Engineering Department, Irbid 22110, Jordan
}

\begin{abstract}
This article examines the seismic fragility of low- and mid-rise $\mathrm{RC}$ infilled frame buildings in Jordan comprising stone-concrete infill panels. Three dimensional models of 2, 4 and 6 story regular and irregular representative buildings were developed. Pushover analyses were performed to construct capacity curves of the model buildings. Four damage states were considered: slight, moderate, extensive and complete and damage state thresholds were assigned, using expert opinion, based on yield and ultimate spectral displacements of the capacity spectra. Sets of preliminary fragility curves were developed to quantify earthquake damage probabilities in terms of spectral displacements.
\end{abstract}

\section{Introduction}

About forty percent of the residential building fabric in Jordan utilizes thin limestone masonry units backed with plain concrete to construct the perimetric exterior walls (referred to hereinafter as stone-concrete walls). This type of construction is concentrated in main cities which are located within a narrow strip alongside the Dead Sea transform fault that constitutes the main active source of seismicity in the country. Construction methods of the exterior stone-concrete (SC) walls changed over the years leading to the current practice wherein gravity load-designed reinforced concrete (RC) building frames are infilled with the multilayer panel. The exterior SC infill panels of today's local construction comprise a layer of stone masonry back-filled with plain concrete and separated from a second layer of concrete masonry by thin polystyrene insulating boards as shown in Fig. 1.

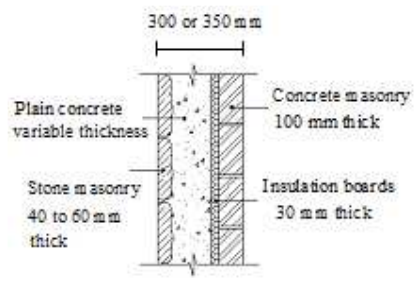

Fig.1. Typical cross section of stone concrete infill panels

\footnotetext{
* Corresponding author: hsnimry@just.edu.jo
} 
To avoid toppling of stone masonry courses during construction, the back-filling concrete is cast in horizontal layers with a time lag of at least $1 \mathrm{hr}$ between the consecutive layers. In practice, this time slot could reach a day or more. Thus, a number of horizontal construction joints are formed, within the plain concrete layer of the wall. On the other hand, concrete masonry (block) is used to construct the interior infill panels which are typically $100 \mathrm{~mm}$ thick. Oftentimes, the same type of concrete blocks but with a thickness of $200 \mathrm{~mm}$ is used in exterior infill walls as a cheaper replacement of SC walls.

During the past two decades a number of experimental studies were conducted to examine the seismic response of SC walls [e.g. 1-3]. Al-Nimry [2] investigated the seismic performance of SC infill walls in gravity load-designed RC frames. Single-story single-bay frame specimens were constructed at one-third scale and tested under reversed cyclic lateral loading. Effects of window openings, axial loading and interface conditions between the infill panel and bounding frame on the seismic response of the frame/infill system were examined. Test results highlighted a major contribution of SC infills in the lateral resistance of the frame/infill system. Observed damage patterns manifested the negative impact of construction joints in the back-filling concrete layer.

This study explores the seismic vulnerability of local and regional building typologies incorporating SC walls. Ideally, ground motion-damage relations (i.e. seismic vulnerability functions) are based on actual earthquake damage data and may be augmented through expert opinion and structural analyses. The lack of such data in Jordan; prompts the use of analytical methods in quantifying seismic vulnerability of rather uncommon (worldwide) but locally dominating building typologies such as those incorporating $\mathrm{SC}$ walls.

\section{Structural models and pushover analysis}

\subsection{General}

To obtain a global insight into the expected earthquake damage probabilities of RC infilled frame residential buildings in Jordan, results of the quasi-static experimentation reported by Al-Nimry [2] were used to model the effect of exterior SC walls on the seismic performance of 2, 4 and 6 story regular and irregular representative buildings. The representative buildings were designed according to local building codes that governed design regulations of RC structures between 1985 and 2005. From an engineering perspective, this time interval spans between the release of the first generation of local design codes for RC structures in 1985 [4] and the release of the first specialized seismic code [5] in 2005 .

Nonlinear static (pushover) analysis was used to arrive at capacity curves of three dimensional (3D) models of the buildings under consideration. Considering 4 damage states, damage state thresholds of the model buildings were defined in terms of yield and ultimate spectral displacements that characterize the bilinear elasto-plastic representation of their capacity curves. Fragility functions were defined using mean spectral displacements and corresponding standard deviation for each damage state.

\subsection{Analytical modeling}

\subsubsection{Representative buildings}

Eight building models representing low-rise and mid-rise residential building typologies constructed in Jordan within the 20-year period preceding enforcement of the first seismic code are considered. Model buildings utilize a structural system of gravity load-designed 
RC infilled frames, with non-ductile detailing, in the two principal directions. To differentiate between two commonly used types of exterior infill panels, the representative buildings are classified into 2 categories: N4 buildings with SC walls along the 4 building sides; and N2 buildings with SC walls along 2 adjacent sides only. In the latter case, exterior frames along 2 sides of the building are infilled with $200 \mathrm{~mm}$-thick concrete masonry walls. Under each of these categories, 2, 4 and 6 story buildings are considered. Furthermore, a 4 story irregular building with a soft story in the ground floor was also considered under each of the $\mathrm{N} 4$ and $\mathrm{N} 2$ building categories. Omitting walls in ground floors of residential buildings is commonly practiced to provide for parking space.

The representative buildings are rectangular in shape with a typical plan area of about $370 \mathrm{~m}^{2}$ (22.6x16.3 outer dimensions), housing two apartments in each floor as shown in Fig. 2. Story heights are equal at $3.25 \mathrm{~m}$ (center to center between floor slabs) and vertical resisting elements are continuous over the building height. One-way ribbed slabs $(250 \mathrm{~mm}$ thick) were used for the roof and typical floor slabs.

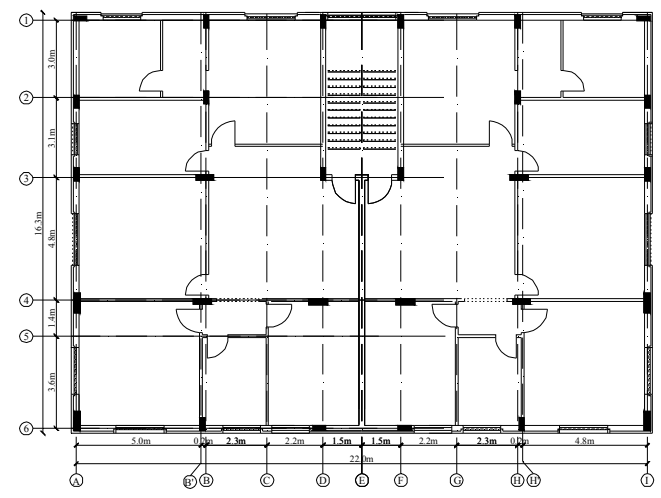

Fig.2. Typical floor plan of representative buildings

Average material properties typically used within the period of interest were adopted for modeling purposes: normal weight concrete is considered with an average 28-day compressive strength, $f_{c}^{\prime}=25 \mathrm{MPa}$ characterized by the Mander et al. [6] stress-strain relation for confined and unconfined concrete. On the other hand, the complete stress-strain curve with strain hardening was used for both main $\left(f_{y}=420 \mathrm{MPa}\right)$ and secondary reinforcement $\left(f_{y v}=280 \mathrm{MPa}\right)$.

\subsubsection{Modeling of structural and nonstructural elements}

Using SAP2000 [7] 3D-models were built for each of the representative buildings. Beam and column elements were modeled as frame elements with lumped plasticity at member ends: Plastic hinges were assigned at a distance equal to $1 / 2$ the plastic hinge length from the joint. Length of the plastic hinge was taken as $1 / 2$ the section depth in direction of loading. Plastic hinge properties were automatically defined by the software according to ATC-40 [8]. The $250 \mathrm{~mm}$-thick roof and floor slabs were assumed to act as rigid diaphragms. Ground floor columns were assumed to be fixed at their bases. Rock with shear wave velocities of about $750 \mathrm{~m} / \mathrm{sec}$ was considered for the local soil profile.

The local concrete masonry/blocks used in infill wall construction are typically produced with a unit compressive strength of about 3.0 MPa. On average, the local mortar mix proportions are 1: 0.5: 4 (cement: lime: aggregates) by volume which can be classified 
as type (ii) mortar in accordance with mix proportions given by BS 5628 [9]. In view of lack experimental data or empirical expressions, characteristic compressive strength $\left(f_{\mathrm{k}}\right)$ of local concrete masonry walls was determined as 3.0 MPa following BS 5628 [9] guidance. Modulus of elasticity for this type of masonry walls was set to $1000 f_{\mathrm{k}}$ as recommended by Eurocode 6 [10]. Cracking strength of the infill panel, $f_{\mathrm{tp}}$, was approximated at $0.25 \mathrm{MPa}$.

Neglecting out-of-plane failure, each infill panel was modeled with a diagonal pair of equivalent compressive struts having the same thickness and modulus of elasticity of the infill panel but with an effective width, a, defined by FEMA 356 [11] as follows:

$$
\begin{aligned}
& a=0.175\left(\lambda_{1} h_{c o l}\right)^{-0.4} r_{\mathrm{inf}} \\
& \lambda_{1}=\sqrt[4]{\frac{E_{m e} t_{\mathrm{inf}} \sin (2 \theta)}{4 E_{f e} I_{c o l} h_{\mathrm{inf}}}}
\end{aligned}
$$

where $h_{\text {col }}$ is the column height between centerlines of beams; $h_{\text {inf }}$ is the height of infill panel; $\mathrm{E}_{\mathrm{fe}}$ is the modulus of elasticity of frame material; $\mathrm{E}_{\mathrm{me}}$ is the modulus of elasticity of infill material; $\mathrm{I}_{\text {col }}$ is the moment of inertia of column; $\mathrm{L}_{\text {inf }}$ is the length of infill panel; $\mathrm{r}_{\text {inf }}$ is diagonal length of infill panel; $t_{\text {inf }}$ is thickness of infill panel and diagonal strut; $\vartheta$ is angle in radians whose tangent is the infill height-to-length aspect ratio and $\lambda_{1}$ is a dimensionless relative stiffness parameter that determines the degree of fame-infill interaction. A tri-linear force-deformation relationship, following the macro model proposed by Fajfar et al. [12] for clay brick infill panels was used to model the nonlinear behavior of concrete masonry infills. Based on ratio of opening area to total infill panel area, the effective width of an equivalent diagonal strut representing an infill wall with an opening was reduced using the stiffness reduction factor, $\lambda$ introduced by Asteris [13]. On the other hand, the SC infill panels were modeled using two nonlinear link elements. Each of these elements was assigned a multi-linear plastic property with nonlinear behavior in the axial direction only as described in Al-Nimry et al. [3].

\subsubsection{Load cases and pushover analysis}

The simultaneous effects of gravity and lateral loads are typically included in the nonlinear analysis of structures. ATC-40 [8] suggests the use of dead loads $(D L)$ and likely live loads $(L L)$ in the analysis of gravity load effects wherein it is suggested to conduct a number of analyses covering the range of possible gravity load levels acting on the structure during an earthquake, and then decide on the most critical value. Mahdi and Darehshiri [14] developed capacity curves for RC buildings subjected to 3 gravity load cases: $1.1 D L+1.1 L L, 0.9 D L$ and $D L+0.2 L L$ and reported insignificant variations in the resulting capacity curves. Accordingly, $25 \%$ of live loads set by the local design code [4] were considered in addition to dead loads for pushover analysis (i.e. $D L+0.25 L L$ ).

Using SAP2000 [7], pushover analysis was performed in two principal directions of the representative buildings to arrive at their capacity curves. Gravity loads were applied first using force control and were followed by a predefined pattern of horizontal forces. Using displacement control, lateral forces were increased monotonically while preserving the ratio between forces applied at the different story levels. Lateral forces were applied to each story following the equivalent lateral force distribution specified in the local seismic code [5]. Use of the inverted triangular lateral load pattern can be justified in view of the high stiffness of residential construction in Jordan wherein recent ambient vibration measurements of fundamental periods of vibration for 6 story buildings of the N4 typology indicated values well below the one-second limit of ATC-40 [8]. To monitor lateral 
displacements in pushover analysis; ATC-40 [8] suggests using one of the top floor/roof nodes as a control node. Keeping in mind that floor slabs were assumed to act as rigid diaphragms, choice of the control node in this case bares no significant effect on the resulting pushover curves.

\section{Capacity curves}

As mentioned in Section 2.2.3, pushover analysis was performed in two principal directions ( $\mathrm{x}$ and $\mathrm{y}$ ) for each building. Conservatively, the pushover curve displaying lower shear capacity between the two resulting curves was considered representative of building capacity. The selected curve was further reduced by $20 \%$ to account for various uncertainties in mathematical modeling.
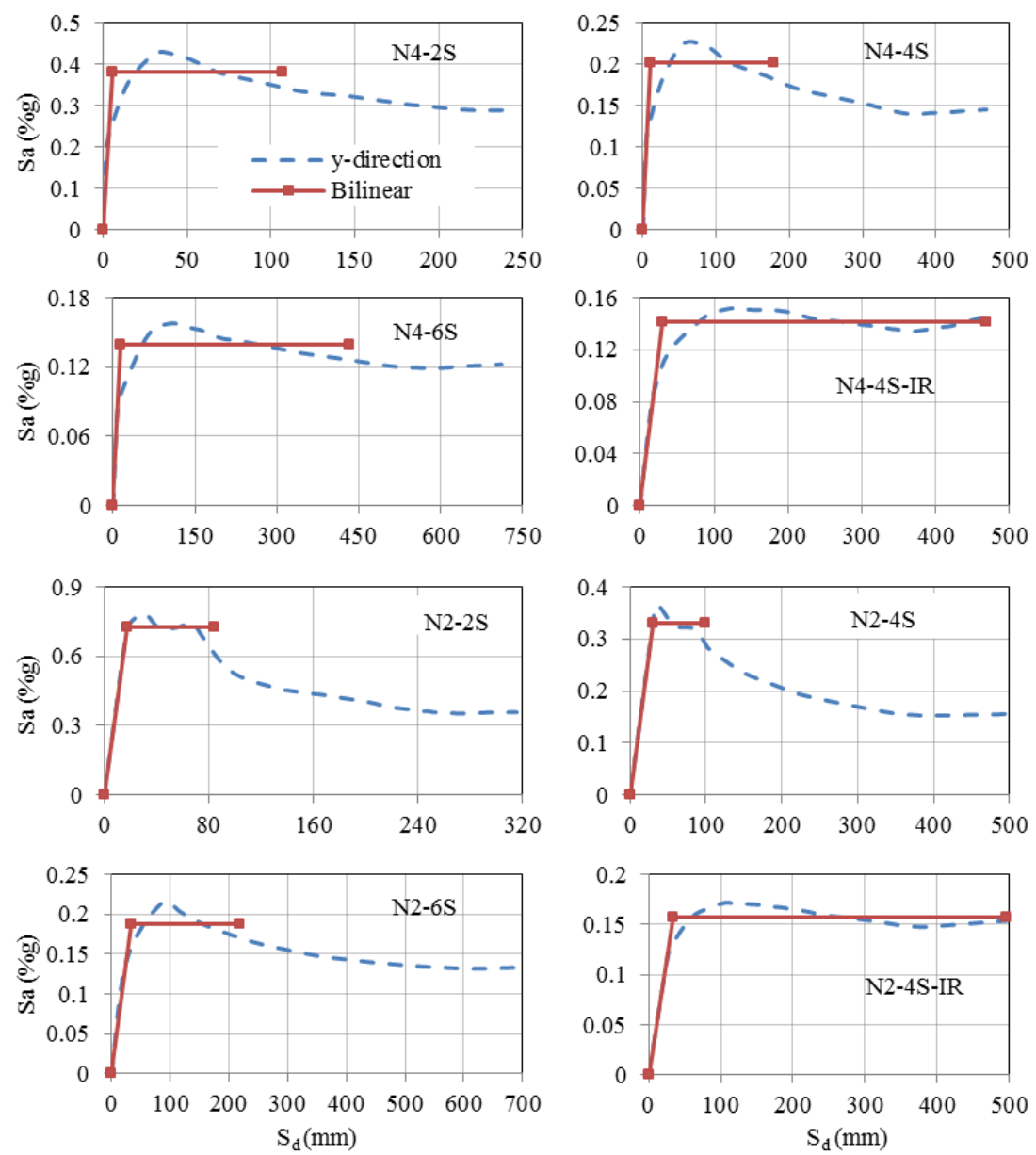

Fig.3. Capacity spectra of low-rise and mid-rise buildings with their bilinear representation 
Analysis results revealed marginal variations in maximum shear capacity of about $2 \%$ and $4 \%$ in buildings of the N4 and N2 typologies, respectively. Shear capacity of N2 buildings was found to be 3 to $6 \%$ less than that of N4 buildings. However, presence of a soft story at ground floor level reduced shear capacity by about $25 \%$ in both building typologies. The actual pushover curve of each representative building was then transferred into acceleration-displacement response spectrum (ADRS) format as displayed in Fig. 3 and idealized using a bilinear elasto-plastic curve for further processing. The yield and ultimate spectral displacements $\left(S_{\mathrm{dy}}\right.$ and $\left.S_{\mathrm{du}}\right)$ and accelerations $\left(S_{\mathrm{ay}}\right.$ and $\left.S_{\mathrm{au}}\right)$ of the idealized capacity curves are summarized in Table 1 .

Table 1. Characteristic displacements and accelerations; damage state thresholds and beta values

\begin{tabular}{|l|c|c|c|c|c|c|c|c|c|c|c|c|}
\hline \multirow{2}{*}{ Building } & \multicolumn{2}{|c|}{$\begin{array}{c}\text { Yield } \\
\text { point }\end{array}$} & \multicolumn{2}{c|}{$\begin{array}{c}\text { Ultimate } \\
\text { point }\end{array}$} & \multicolumn{4}{|c|}{ Damage state thresholds (spectral displacements in mm) } \\
\cline { 2 - 16 } & $\begin{array}{c}S_{\mathrm{dy}} \\
(\mathrm{mm})\end{array}$ & $\begin{array}{c}S_{\mathrm{ay}} \\
(\% \mathrm{~g})\end{array}$ & $\begin{array}{c}S_{\mathrm{du}} \\
(\mathrm{mm})\end{array}$ & $\begin{array}{c}S_{\text {au }} \\
(\% \mathrm{~g})\end{array}$ & $S_{\mathrm{d} 1}$ & $\beta_{1}$ & $S_{\mathrm{d} 2}$ & $\beta_{2}$ & $S_{\mathrm{d} 3}$ & $\beta_{3}$ & $S_{\mathrm{d} 4}$ & $\beta_{4}$ \\
\hline N42S & 6.1 & 0.38 & 107.4 & 0.38 & 4.3 & 0.75 & 6.1 & 0.80 & 82.1 & 1.0 & 107.4 & 1.0 \\
\hline N44S & 11.0 & 0.20 & 179.1 & 0.20 & 7.7 & 0.65 & 11.0 & 0.73 & 137.1 & 0.93 & 179.1 & 0.93 \\
\hline N44S-R & 29.8 & 0.14 & 468.2 & 0.14 & 20.9 & 0.70 & 29.8 & 0.76 & 358.6 & 0.96 & 468.2 & 0.96 \\
\hline N46S & 14.2 & 0.14 & 433.6 & 0.14 & 9.9 & 0.65 & 14.2 & 0.73 & 328.8 & 0.93 & 433.6 & 0.93 \\
\hline N2-2S & 17.1 & 0.73 & 84.1 & 0.73 & 12.0 & 0.75 & 17.1 & 0.85 & 67.3 & 1.0 & 84.1 & 1.05 \\
\hline N24S & 30.0 & 0.33 & 98.6 & 0.33 & 21.0 & 0.65 & 30.0 & 0.80 & 81.5 & 1.0 & 98.6 & 1.0 \\
\hline N24S-R & 35.0 & 0.16 & 495.9 & 0.16 & 24.5 & 0.65 & 35.0 & 0.80 & 380.7 & 0.93 & 495.9 & 0.93 \\
\hline N2-6S & 33.5 & 0.19 & 218.4 & 0.19 & 23.5 & 0.65 & 33.5 & 0.80 & 172.2 & 1.0 & 218.4 & 1.0 \\
\hline
\end{tabular}

${ }^{1} \mathrm{~N} 4$ and $\mathrm{N} 2$ designate the building typology; 2S, 4S and 6S designate the number of stories; IR designates the irregularity due to soft story at ground floor level.

\section{Development of fragility curves}

Earthquake motion-damage relations, usually expressed in the form of fragility curves, are vital for seismic risk evaluations and earthquake scenario simulations. Fragility curves of the buildings under consideration (see Fig. 4) were developed to display the probability of being in a specific damage state $P(\mathrm{~d} \geq \mathrm{ds})$ versus the spectral displacement $S_{\mathrm{d}}$ which defines the level of seismic action. Four damage states are defined: slight, moderate, major/extensive and complete as signified by the numbers 1, 2, 3 and 4, respectively. For a specific damage state, the fragility curve is described by the lognormal probability density function given in Eq. (3)

$$
P\left[d s \mid S_{d}\right]=\Phi\left[\frac{1}{\beta_{d s}} \ln \left(\frac{S_{d}}{S_{d, d s}}\right)\right]
$$

where $S_{\mathrm{d}, \mathrm{ds}}$ is the median value of spectral displacement at which the building reaches the threshold of damage state, $\mathrm{ds} ; \beta_{\mathrm{ds}}$ is the standard deviation of the natural logarithm of spectral displacement for damage state, ds; and $\Phi$ is the standard normal cumulative distribution function. Using expert opinion, mean values for damage state thresholds $S_{\mathrm{d}, \mathrm{ds}}$ are related to yield and ultimate spectral displacements characterizing the bilinear representation of the capacity spectra as follows

$$
\begin{array}{ll}
\text { Slight: } & S_{\mathrm{d}, 1}=0.70 S_{\mathrm{dy}} \\
\text { Moderate: } & S_{\mathrm{d}, 2}=S_{\mathrm{dy}} \\
\text { Extensive: } & S_{\mathrm{d}, 3}=S_{\mathrm{dy}}+0.75\left(S_{\mathrm{du}}-S_{\mathrm{dy}}\right) \\
\text { Complete: } & S_{\mathrm{d}, 4}=S_{\mathrm{du}}
\end{array}
$$


To quantify the variability of fragility curves for each damage state, lognormal standard deviation $\left(\beta_{\mathrm{ds}}\right)$ values were developed based on values suggested in HAZUS-MH-MR4 [15]. To this aim, the following were assumed: 1) structural systems in the buildings under consideration exhibit moderate variability of the capacity curves, that is $\beta_{\mathrm{c}}=0.3 ; 2$ ) small damage variability $\left(\beta_{\mathrm{T}, \mathrm{ds}}=0.2\right)$ for slight and moderate damage; 3$)$ moderate damage variability $\left(\beta_{\mathrm{T}, \mathrm{ds}}=0.4\right)$ for extensive and complete damage; and 4$)$ the post yield degradation factor $(\kappa)$ is defined in accordance to Table 2. Accordingly, the Beta values were derived from the Beta tables (Tables 6.5 and 6.6) in HAZUS-MH-MR1 [16] for lowand mid-rise buildings, respectively.

Table 2. Post yield degradation factor, $\kappa$

\begin{tabular}{|l|l|l|l|}
\hline \multirow{2}{*}{$\begin{array}{l}\text { Building } \\
\text { typology }\end{array}$} & \multicolumn{3}{|l|}{ Degradation factor } \\
\cline { 2 - 4 } & At $1 / 2$ yield & At yield & Post yield/moderate shaking duration \\
\hline $\mathrm{N} 4$ & 1 & 0.7 & 0.3 \\
\hline $\mathrm{N} 2$ & 1 & 0.5 & 0.1 \\
\hline
\end{tabular}
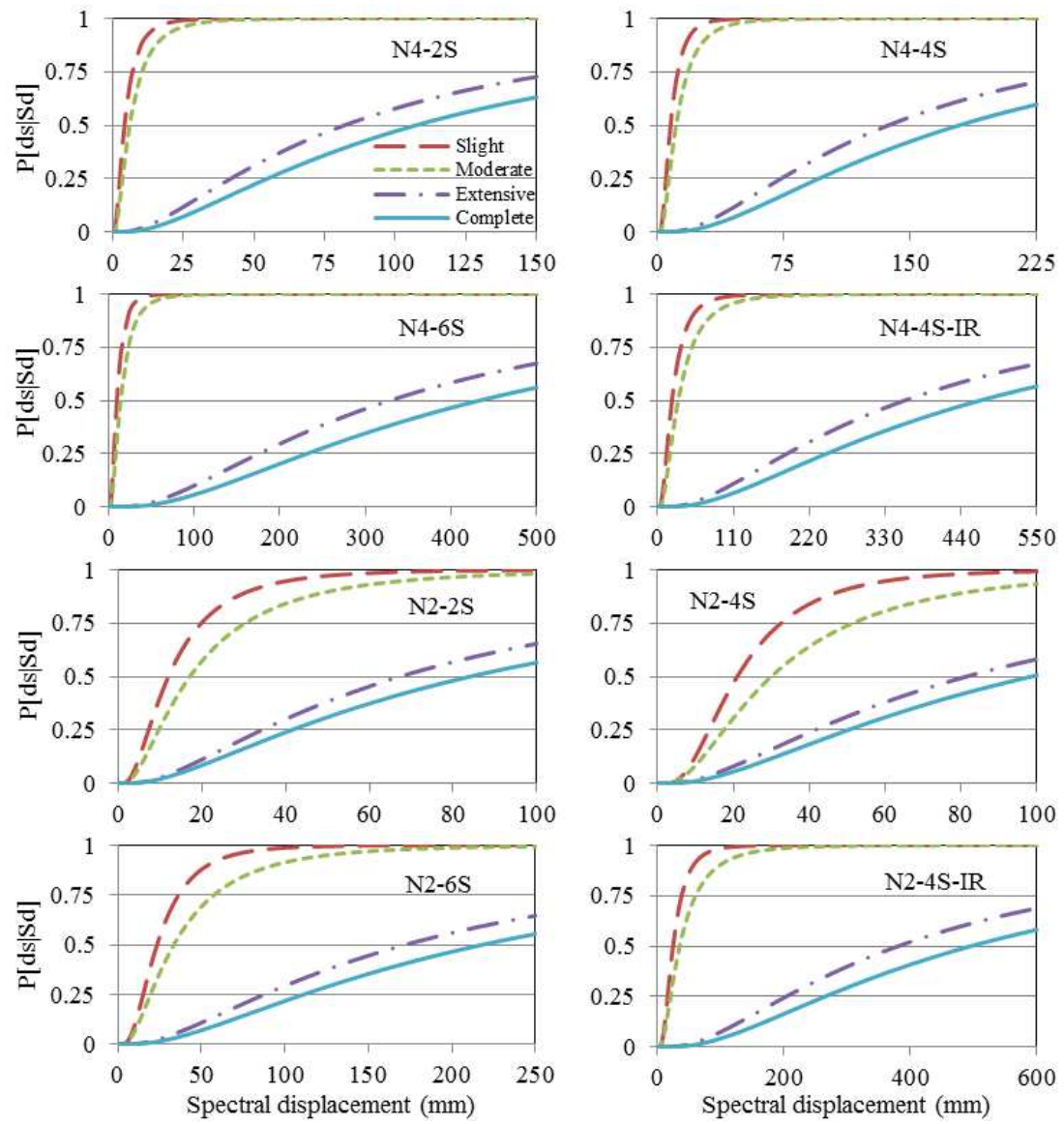

Fig.4. Fragility curves of residential low- and mid-rise N4 and N2 buildings 


\section{Results and Conclusions}

The 4 damage state thresholds and corresponding Beta values for the N4 and N2 buildings are summarized in Table 1. Fragility curves developed for the representative buildings are displayed in Fig. 4. The fragility curves developed in this study may be considered as preliminary functions that could be used in earthquake risk scenarios in Jordan. Further refinement of such curves is deemed necessary to take into account the possible variability in input parameters that have been adopted for the nonlinear analysis, the definition of damage state thresholds, as well as the variability of fragility curves for each of the damage states considered. Furthermore, validity of the vulnerability functions remains a critical issue in view of the absence of earthquake damage data which is usually needed to calibrate the levels of damage suggested by these functions.

\section{References}

1. M. Abdel-Halim, S. Barakat, Cyclic performance of concrete-backed stone masonry walls. J. Struct. Eng. ASCE 129(5): 596-605 (2003)

2. H. Al-Nimry, Quasi-static testing of RC infilled frames and confined stone-concrete bearing walls. J. Earthq. Eng. 18(1):1-23 (2014)

3. H. Al-Nimry, M. Resheidat, S. Qeran, Rapid assessment for seismic vulnerability of low and medium rise infilled RC frame buildings. Eng. Eng. Vib. 14(2): 275-293 (2015)

4. Jordanian National Building Council, Code for Loads and Forces (1985)

5. Jordanian National Building Council, Code for Earthquake-Resistant Buildings (2005)

6. J. Mander, M. Priestley, R. Park, Theoretical stress-strain model for confined concrete. J. Struct. Eng. ASCE 114 (8): 1804-1826 (1988)

7. Computers and Structures, Inc., SAP2000 v14, Integrated Solution for Structural Analysis and Design (2009)

8. ATC-40: Seismic Evaluation and Retrofit of Concrete Buildings. Applied Technology Council, California, USA (1996)

9. British Standards Institution. BS 5628-1:1992 Code of Practice for Use of Masonry. Part 1: Structural Use of Unreinforced Masonry (1992)

10. European Committee for Standardization CEN 2004. Eurocode 6: Design of Masonry Structures. Part 1-1: General Rules for Reinforced and Unreinforced Masonry Structures. prEN 1996-1-1:2004

11. FEMA-356: Prestandard and Commentary for the Seismic Rehabilitation of Buildings. Federal Emergency Management Agency (2000)

12. P. Fajfar, M. Dolsek, R. Zarnic, S. Gostic, Development of numerical methodologies for infilled frames, Towards European Integration in Seismic Design and Upgrading of Building Structures Project. Euroquake-Project, Final Report (2001)

13. P. Asteris, Lateral stiffness of brick masonry infilled plane frames. J. Struct. Eng. ASCE 129(8): 1071-1079 (2003)

14. T. Mahdi, H. Darehshiri, Pushover analysis of asymmetric ordinary moment R.C frames designed according to the Iranian codes. $3^{\text {rd }}$ Int. Conf. on Concrete and Development, Tehran (2009)

15. HAZUS-MH-MR4 Technical Manual, Federal Emergency Management Agency (2003)

16. HAZUS-MH-MR1 AEBM: Technical and User's Manual, Federal Emergency Management Agency (2003) 